\title{
The influence of fire and livestock grazing on the assemblage of non-flying small mammals in grassland-Araucaria Forest ecotones, southern Brazil
}

\author{
Ezequiel Pedó1,4; Thales R. O. de Freitas ${ }^{1,3}$ \& Sandra M. Hartz ${ }^{1,2}$ \\ 1 Programa de Pós-Graduação em Ecologia, Universidade Federal do Rio Grande do Sul. Caixa Postal 15007, \\ 91501-970 Porto Alegre, RS, Brazil. \\ ${ }_{2}^{2}$ Departamento de Ecologia, Instituto de Biociências, Universidade Federal do Rio Grande do Sul. Caixa Postal 15007, \\ 91501-970 Porto Alegre, RS, Brazil. \\ ${ }^{3}$ Departamento de Genética, Instituto de Biociências, Universidade Federal do Rio Grande do Sul. Caixa Postal 15007, \\ 91501-970 Porto Alegre, RS, Brazil. \\ ${ }^{4}$ Corresponding author. E-mail address: ezequiel.pedo@gmail.com
}

\begin{abstract}
Grazing and fire, used in pasture regeneration practices, are inter-related activities in livestock management. Both activities affect habitat characteristics by changing the structure of the herbaceous and shrubby vegetation, reducing their biomass and litter cover. This study evaluated the effect of fire and livestock grazing on the assemblage of nonflying small mammals in grassland-Araucaria forest ecotones in southern Brazil. We compared four areas frequently affected by livestock management with four protected areas. Surveys were carried out in four sampling periods, one in each season of 2004. We captured a total of 325 individuals from 12 species of rodents - Akodon montensis Thomas, 1913, Akodon paranaensis Christoff, Fagundes, Sbalqueiro, Mattevi e Yonenaga-Yassuda, 2000, Akodon sp. 1, Akodon sp. $2(2 \mathrm{n}=34)$, Brucepattersonius iheringi (Thomas, 1896), Delomys dorsalis (Hensel, 1872), Oligoryzomys flavescens (Waterhouse, 1837), Oligoryzomys nigripes (Olfers, 1818), Oxymycterus nasutus (Waterhouse, 1837), Scapteromys sp. $(2 \mathrm{n}=34)$, Sooretamys angouya (Fischer, 1814) and Thaptomys nigrita (Lichtenstein, 1829) - and two species of marsupials - Monodelphis dimidiata (Wagner, 1847) and Philander frenatus (Olfers, 1818) -, in a total effective effort of 5254 traps.day ${ }^{-1}$. The abundance, biomass and diversity of non-flying small mammals were significantly higher in the protected areas than in those affected by fire and livestock grazing. Species strictly associated with grassland habitats were not found in the impacted area. These results indicate that the presence of herds of domestic ungulates negatively affect the assemblage of non-flying small mammals in grassland and Araucaria forest areas in southern Brazil.
\end{abstract}

KEY WORDS. Atlantic Forest; Campos; Didelphimorphia; habitat loss; Rodentia.

The presence of large domestic herbivores in a landscape is generally associated with understory and litter cover reduction and soil compaction, resulting in significant environmental impact that can affect ecosystem nutrient cycle and energy flow (Frank \& Evans 1997, Frank \& Groffman 1998). In the northwestern United States, grazing has not been found to have a significant effect on bird species, but seems to negatively affect the assemblage of non-flying small mammals, which have more restricted mobility (MOSER \& WITMER 2000). Even though richness, abundance and diversity of this group are lower in grazed areas when compared with non-grazed ones (MOSER \& WITMER 2000), non-flying small mammal species often respond differently to grazing. Species that have more strict resource requirements (habitat specialists) tend to be more negatively affected than habitat generalists (Nupp \& SWIHART 2000). Habitat loss is considered the major threat to biodiversity conservation in terrestrial ecosystems around the world (BRooks et al. 2002), and species extinc- tions in grasslands negatively affect ecosystem stability and productivity (Tilman \& Downing 1994, Tilman et al. 1996).

The Araucaria forest (mixed ombrophilous forest, sensu Teixeira \& Coura Neto 1986) is physiognomically characterized by the dominance of Araucaria angustifolia (Bertol.) Kuntze. It is part of the Atlantic Forest domain, one of the top five biodiversity hotspots in the world, and one of the most threatened ecosystems (Myers et al. 2000), with $11.4 \%$ to $16 \%$ of its original cover currently remaining (Ribeiro et al. 2009). Araucaria forests constitute the main forest type on the highland plateau in southern Brazil at altitudes above $500 \mathrm{~m}$ a.s.l.; this forest often forms mosaics with natural grasslands (DUARTE et al. 2006). The natural succession of grasslands by Araucaria forests, which started around 1200 years ago (BeHLING et al. 2004), has been hindered by human impact, particularly anthropogenic fire. In southern Brazil, grasslands are often subjected to periodic burnings during the process of pasture regeneration for livestock use (BEHLING 
\& Pillar 2007). Fire affects habitat dynamics radically by removing virtually all plant biomass from the soil, and by creating a positive feedback mechanism that increases susceptibility to fire and fire intensity (Cochrane \& SCHUlze 1999, Cochrane et al. 1999). This particular disturbance causes a sudden but relatively short change in the dynamics of non-flying small mammal populations (Ojeda 1989, Fa \& Sanchez-Cordero 1993), favoring some species at the expense of others (Price \& Waser 1984, Vieira \& Marinho-Filho 1998, Vieira 1999, Simon et al. 2002, Figueiredo \& FERNANDEZ 2004). Apparently, fire causes no significant direct mortality on these animals. Instead, it compels non-flying small mammals to flee (VIEIRA \& MarINHO-FILHO 1998) or to find protection in subterraneous dens (Simons 1991).

The aim of this study was to assess the influence of habitat degradation by fire and grazing on the assemblage of nonflying small mammals in grassland-Araucaria forest ecotones in southern Brazil.

\section{MATERIAL AND METHODS}

This study was carried out in 2004, in the municipality of São Francisco de Paula, in the northwestern region in the state of Rio Grande do Sul, southern Brazil (Fig. 1). According to Teixeira \& Coura Neto (1986), this region comprises three phytoecological zones: grassy-woody savanna (grasslands) and mixed ombrophilous forest (Araucaria forest), located in higher sections of smoother relief, and dense ombrophilous forest (Atlantic forest), found in steep scarp slopes.

Local climate is temperate ('Cfb' type, according to Köppen (1948)) characterized by well-distributed rainfalls throughout the year and average temperature lower than $22^{\circ} \mathrm{C}$ in the warmest summer month (KöPPEN 1948). The average annual number of frost days is 21 to 26 , and short-duration snowfall may occasionally occur in June, July and August (Moreno 1961). According to data collected between 1931 and 1960 at the São Francisco de Paula Meteorological Station $\left(29^{\circ} 20^{\prime} \mathrm{S}\right.$ and $50^{\circ} 31^{\prime} \mathrm{W}$, $912 \mathrm{~m}$ ), average annual rainfall is $2253 \mathrm{~mm}$ and average annual temperature is $14.5^{\circ} \mathrm{C}$ (average maximum temperature: $20.3^{\circ} \mathrm{C}$; average minimum temperature: $9.9^{\circ} \mathrm{C}$ ), reaching $34^{\circ} \mathrm{C}$ in December and $-6.5^{\circ} \mathrm{C}$ in July (Brasil 1969). There is a considerable surplus of water throughout the year (Brasil 1969). Dense fog and orographic rain are also very common.

We selected eight areas for sampling, located between $29^{\circ} 27^{\prime} 58^{\prime \prime}-29^{\circ} 29^{\prime} 17^{\prime \prime} \mathrm{S}$ and $50^{\circ} 12^{\prime} 0^{\prime \prime}-50^{\circ} 13^{\prime} 26^{\prime \prime} \mathrm{W}$. A control and a treatment group were defined, each with four areas. The control group has been protected from livestock grazing and grassland fire since 1994 (Centro de Pesquisas e Conservação da Natureza Pró-Mata, with an area of ca. 2500ha, hereafter named 'protected area'), while the treatment group is located in a ranch (near the protected area) subject to extensive management of cattle and pig herds, and periodic grassland burning (every one or two years) (Fazenda Três Estrelas, with an area of approximately 500ha, hereafter named 'impacted area').
One sampling area in both protected and impacted sites was located in grassland-continuous Araucaria forest ecotones, while the other three areas in each group were located in ecotones between grasslands and Araucaria forest patches (Fig. 1). The three forest patches from the protected area had $0.15,0.22$ and $0.24 \mathrm{ha}$, while patches from the impacted area had 0.12 , 0.22 and $0.36 \mathrm{ha}$. Even though selective logging of native trees has happened in both areas in the past, logging of native trees has not taken place in the last 20 years.

A detailed description of the physiognomy of the vegetation of the protected area can be found in Oliveira \& Pillar (2004) and Duarte et al. (2006).

We carried out surveys of non-flying small mammals in four campaigns, one in each season of 2004. Since nights with high luminosity are associated with changes in wildlife activity patterns, which are interpreted as a response to increased predation risk, campaigns were carried out in periods when luminosity was lower, in the same lunar phase (KaUfMAN \& Kaufman 1982, Price et al. 1984, Bowers 1988, Brown et al. 1988, BItTencourt et al. 1999). Trapping efforts per campaign totaled fourteen, 24- hour periods (except in winter, with only three periods). The first seven consecutive periods were spent in both grassland-continuous Araucaria forest ecotones, while the remaining seven were spent in the six grassland-Araucaria forest patch ecotones.

We used 144 traps (cage type, 30x14x14 cm) in each 24hour period (hereafter day). Each trapping station was placed $15 \mathrm{~m}$ apart from the others and had two traps placed at ground level. Half of the stations were placed in the grassland and the other half in the Araucaria forest. Stations were allocated equally between the impacted and protected areas. Sampling in both areas was simultaneous, and trapping effort per area was the same (3240 traps.day $\left.{ }^{-1}\right)$. Total trapping effort (for both areas) was 6480 traps.day $^{-1}$. Traps were baited with corn and a mixture of wheat flower, peanut sweet (roasted and crushed peanuts mixed with sugar and manioc flour) and fish.

Three transects were distributed in each grassland-continuous Araucaria forest ecotones. Each transect had 12 trapping stations, totaling 36 stations. In grassland-Araucaria forest patch ecotones, we established only two transects. Number of trapping stations per transect, in this case, was four, six or eight, according to patch size. In order to avoid problems in comparing different patches, we selected six Araucaria forest patches based on their similarity (shape and size), leaving treatment (grazing and fire present or absent) as the main difference between them.

Captured individuals were identified, marked by ear puncturing, measured (body and tail length), weighted and sexed. We collected at least one individual of each captured species for deposition in the mammal collections of the Museu de Ciências e Tecnologia of the Pontifícia Universidade Católica do Rio Grande do Sul (MCT-PUCRS) and of the Museu Nacional do Rio de Janeiro (MNRJ). 


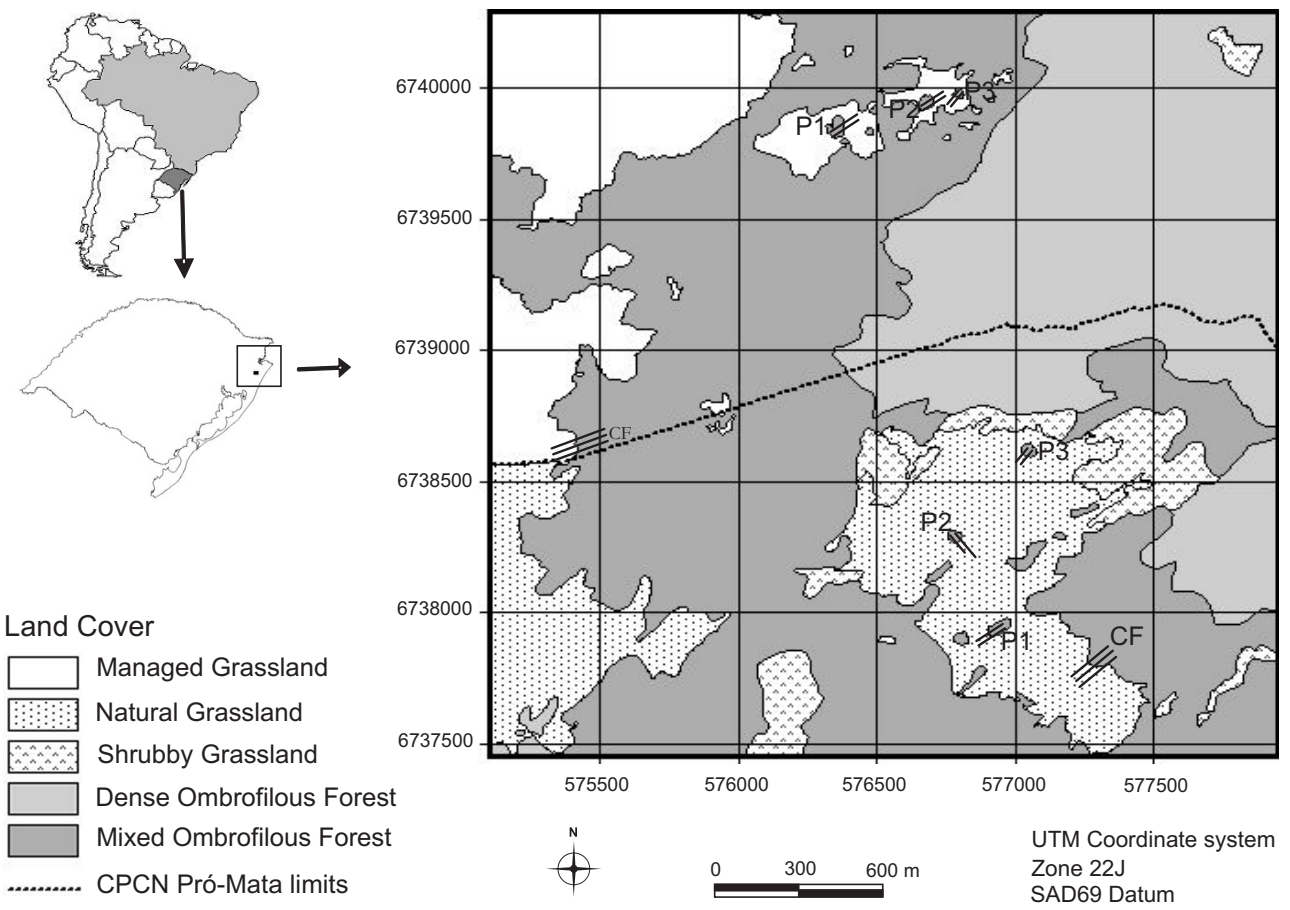

Figure 1. Study site location (land use and land cover maps), with use of ArcView GIS 3.2). Abbreviations of sampling areas: (CF) transects in grassland-continuous forest ecotones; (P1, P2 and P3) transects in different grassland-forest patch ecotones). The impacted area (Fazenda Três Estrelas) is located northwards from the divider indicated in the map while the protected area (CPCN Pró-Mata) is southwards.

We compared impacted and protected areas using abundance (number of individuals) and biomass (in grams) per mammal species. Data matrices were generated using an abundance index calculated as the number of individuals per species divided by trapping effort in the four sampling campaigns, in each sampling unit (i.e. trapping station).

To compare the composition of non-flying small mammals between areas under different management regimens (i.e. impacted or protected), we used MULTIV version 2.3.17 (PILLAR 2005), a multivariate statistics software that generates similarity statistics and undertakes analysis of variance using randomization tests (non-parametric hypothesis testing), as proposed by Pillar \& Orlóci (1996). In the analysis of variance, total variation is partitioned into 'between-group' and 'within-group' variation (MANLY 1997). The purpose of variance partitioning is to assess, by means of the probability $(\mathrm{P})$ obtained in randomization tests, the magnitude of 'between-group' variation, and whether groups differ or not. Partitioning was performed by means of the sum of squared Euclidean distances between sampling units. The randomization test generates a probability $(\mathrm{P})\left(\mathrm{Qb}^{\circ} \geqslant \mathrm{Qb}\right.$, where the random sum of squares is greater than or equal to the observed sum of squares) used to reject or accept the null hypothesis $\left(\mathrm{H}_{0}\right)$. The null hypothesis is rejected if $P$ is lower than or equal to $\alpha(0.1)$, and is accepted if there is no significant difference between protected and impacted areas. To test the hypothesis, 1000 iterations were applied.

Trapping effort per sampling unit was uneven throughout the year, because traps were occasionally disarmed by weather, cattle or predators - mainly the crab-eating fox, Cerdocyon thous (Linnaeus, 1766). To overcome this problem, we estimated the average number of individuals per trap.day ${ }^{-1}$ in each sampling unit for comparison between the two areas, and probability $(\mathrm{P})$ was estimated as described previously. Biomass data were analyzed similarly, but trapping effort was lower due to loss of body mass information in predated individuals, from which only skulls remained for identification. We also estimated Shannon diversity indices (ZAR 1996) and trapping success for each area.

\section{RESULTS}

The total effective capture effort was 5254 traps.day $^{-1}$. We had 718 successful captures, which included 325 individuals from 14 species of non-flying small mammals. Species included 12 sigmodontine rodents and two marsupials (Tab. I). New morphotypes of Akodon Meyen, 1833 and Scapteromys Waterhouse, 1837 , both with a diploid number of 34 chromosomes - named Akodon sp. $2(2 \mathrm{n}=34)$ and Scapteromys sp. $(2 \mathrm{n}$ 
Table I. Abundance and diversity of non-flying small mammals in areas protected and impacted by fire and livestock grazing in grasslandAraucaria forest ecotones in southern Brazil, in 2004 (trapping effort of 2327 traps.day $^{-1}$ in the protected area and 2927 traps.day $^{-1}$ in the impacted area).

\begin{tabular}{|c|c|c|c|c|}
\hline \multirow{2}{*}{ Species } & \multicolumn{2}{|c|}{ Number of individuals } & \multicolumn{2}{|c|}{ Individuals/100 traps.day ${ }^{-1}$} \\
\hline & Protected area & Impacted area & Protected area & Impacted area \\
\hline \multicolumn{5}{|l|}{ Didelphimorphia: Didelphidae } \\
\hline Monodelphis dimidiata & 10 & - & 0.43 & - \\
\hline Philander frenatus & 1 & - & 0.04 & - \\
\hline \multicolumn{5}{|l|}{ Rodentia: Cricetidae } \\
\hline Akodon montensis & 46 & 15 & 1.98 & 0.51 \\
\hline Akodon paranaensis & 6 & - & 0.26 & - \\
\hline Akodon sp. 1 & 1 & - & 0.04 & - \\
\hline Akodon sp. $2(2 \mathrm{n}=34)$ & 43 & - & 1.85 & - \\
\hline Brucepattersonius iheringi & 2 & - & 0.09 & - \\
\hline Delomys dorsalis & 7 & 3 & 0.30 & 0.10 \\
\hline Oligoryzomys flavescens & 3 & - & 0.13 & - \\
\hline Oligoryzomys nigripes & 51 & 43 & 2.19 & 1.47 \\
\hline Oxymycterus nasutus & 87 & - & 3.74 & - \\
\hline Scapteromys sp. $(2 \mathrm{n}=34)$ & 1 & - & 0.04 & - \\
\hline Sooretamys angouya & - & 1 & - & 0.03 \\
\hline Thaptomys nigrita & 5 & - & 0.21 & - \\
\hline Total & 263 & 62 & 11.3 & 2.12 \\
\hline Shannon index $\left(\mathrm{H}^{\prime}\right)$ & 1.82 & 0.81 & & \\
\hline
\end{tabular}

=34), respectively) - were captured and remain to be described. We were also unable to identify one captured individual (Akodon sp. 1) because it did not match morphological characteristics of any previously described species.

Thirteen species were captured in the protected area and four species were captured in the impacted area. Ten species were found only in the protected area, three in both areas, and Sooretamys angouya (Fischer, 1814) was only found in the impacted area (a single individual was captured). The number of captured individuals and the Shannon diversity index were also higher in the protected area (four and two times higher, respectively) (Tab. I). Capture success was five times higher $(25.1 \%$ to $4.58 \%$ ) too.

The average number of individuals per sampling unit was 6.75 in the protected area and 1.37 in the impacted area. No captures occurred in more than a half of the sampling units (37, from which 34 were in grasslands) in the impacted area (Figs 2 and 3).

Similarly, the average number of individuals per trap.day${ }^{1}$ in each sampling unit of the protected area was 6.5 times higher than in the impacted area (Randomization test, $\mathrm{p}=$ 0.001) (Fig. 4). By applying the same analysis to the biomass data, we found that the average biomass per trap.day ${ }^{-1}$ in each sampling unit was 9.6 times higher in the protected area (Randomization test, $\mathrm{p}=0.001$ ) (Fig. 5).

The results of the multivariate analysis indicate a significant difference in the composition of non-flying small mammals of the two areas, either when data on abundance of individuals per species (Randomization test, $\mathrm{p}=0.001$ ) or biomass per species (Randomization test, $p=0.001$ ) were used. In these analyses, the effects of factors that might have interfered in the results, such as habitat type (grassland or forest) and distance to borders, were excluded. The results of the test indicated a significant interaction between the factors 'habitat type' ( $p=0.001$, either for abundance or biomass) and 'distance to border' ( $p=0.057$ for abundance and $p=0.019$ for biomass) on the analyzed factor: 'management'. Therefore, each habitat type was compared separately, according to management type. By excluding the effect of the factor 'distance to border', we found a significant difference between the protected and impacted areas in grassland $(p=0.001$, either for abundance or biomass) and forest habitats ( $\mathrm{p}=0.001$ for abundance and $\mathrm{p}=$ 0.003 for biomass).

Richness and diversity of non-flying small mammals in grassland habitats were higher than in forest habitats (richness: grasslands $=11$ species, forests $=10$; diversity (Shannon 

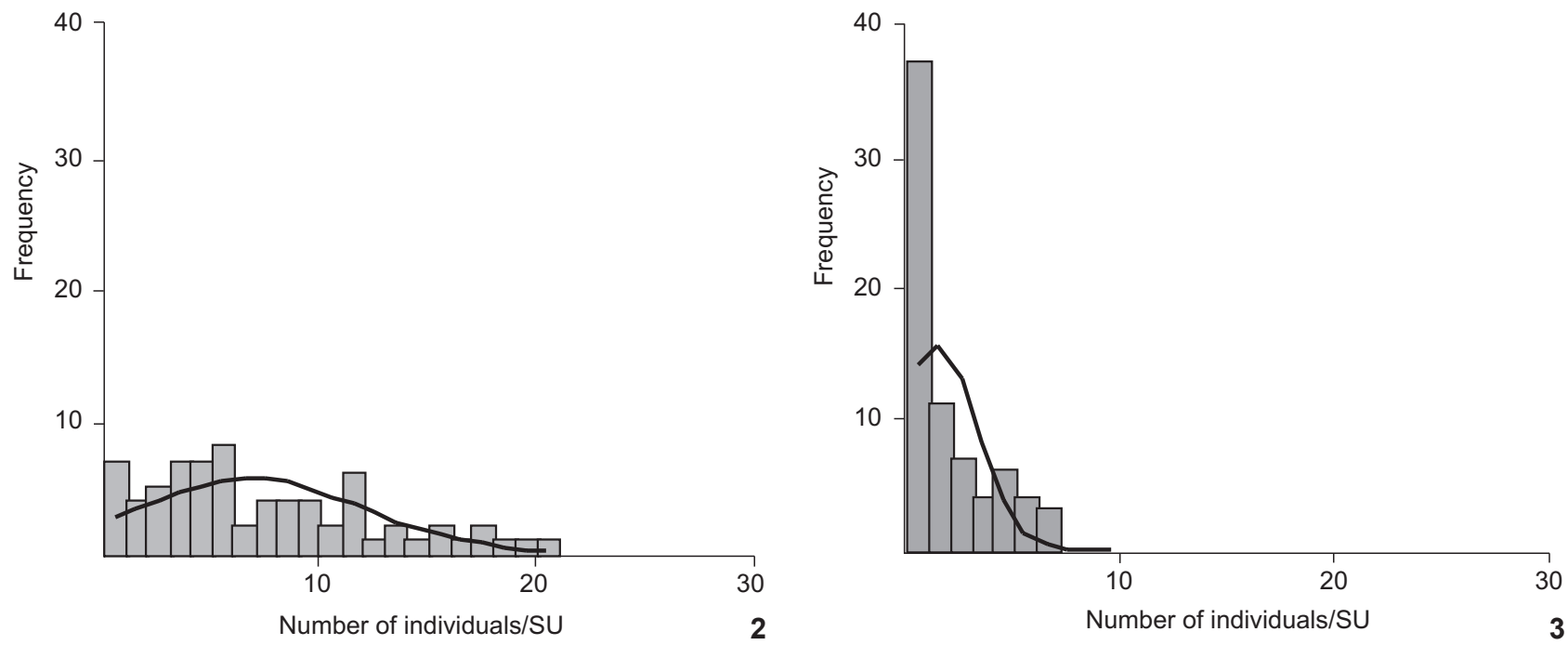

Figures 2-3. Frequency of number of individuals of non-flying small mammals per sampling unit (trapping station) in (2) protected areas and (3) areas impacted by fire and livestock grazing in grassland-Araucaria forest ecotones in southern Brazil, in 2004 (144 sampling units, a half for each area). The line represents a normal curve.
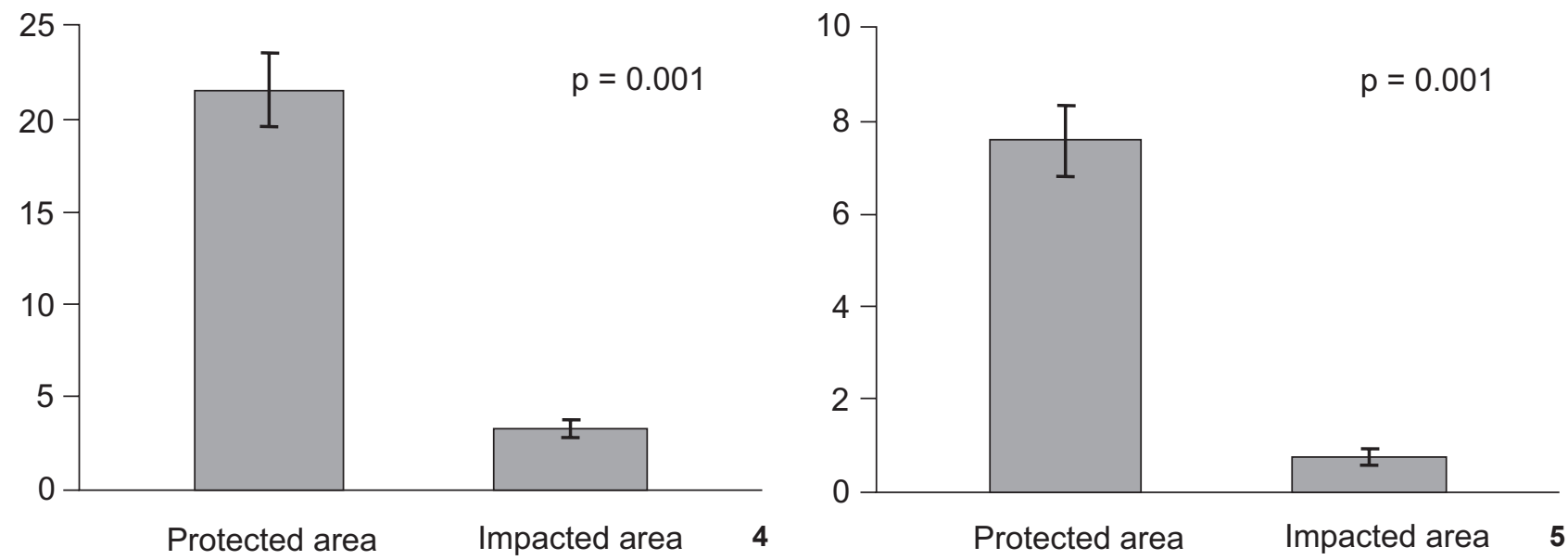

Figures 4-5. Distribution of mean values (with standard errors) of (4) the number of individuals and (5) biomass (g) per trap.day ${ }^{-1}$ in each sampling unit (x100) - trapping effort: 2327 traps.day $^{-1}$ in the protected area and 2927 traps.day ${ }^{-1}$ in the impacted area; 144 sampling units, a half for each area - in protected areas and in areas impacted by fire and livestock grazing in grassland-Araucaria forest ecotones in southern Brazil, in 2004.

Index): grasslands $=1.619$, forests $=1.255)$. However, only two individuals of Oligoryzomys nigripes (Olfers, 1818) were captured in grasslands located in ecotones under the effect of livestock grazing (Fig. 6). In impacted areas located in forest habitats, the abundance of this species was $80 \%$ higher than in protected areas (Fig. 6). Differences in species richness and total abundance of individuals remained high, but were lower between both areas in this habitat.

\section{DISCUSSION}

Research on the effects of disturbances such as fire and livestock grazing on non-flying small mammals, encompassing several biomes around the world, has focused on fire experiments (Beck \& Vogl 1972, Price \& Waser 1984, Ojeda 1989, Fa \& Sanchez-Cordero 1993, Vieira \& Marinho-Filho 1998, Figueiredo \& Fernandez 2004). However, researchs in grassland- 


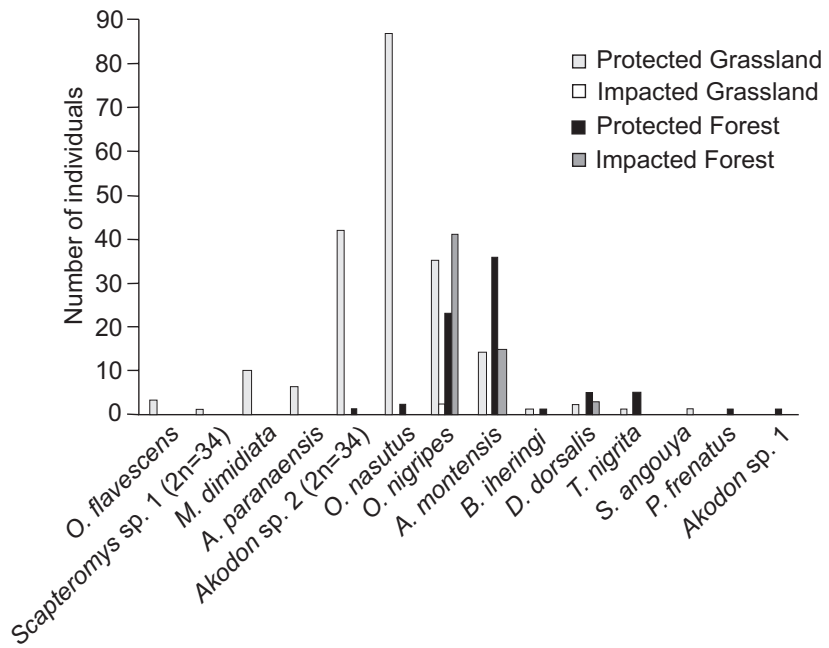

Figure 6. Total number of individuals captured in grassland and forest areas, protected and impacted by fire and livestock grazing in southern Brazil, in 2004 (trapping effort: 1080 traps.day $^{-1}$ in protected grassland, 1409 traps.day $^{-1}$ in impacted grassland, 1247 traps.day ${ }^{-1}$ in protected forest and 1518 traps.day $^{-1}$ in impacted grassland).

Araucaria forest ecotones are lacking. This study presents the first analysis in this kind of environment. Moreover, our sampling design is relatively different from other studies, which usually compare the assemblage of non-flying small mammals before and after a disturbance, and monitor the process of recolonization of impacted areas (such as Simons (1991), FA \& Sanchez-Cordero (1993), Vieira \& Marinho-Filho (1998), Vieira (1999) and Figueiredo \& Fernandez (2004). Our findings indicate that richness, abundance, diversity and biomass of nonflying small mammals in grassland-Araucaria forest ecotones subjected to frequent fires and livestock grazing is lower than in areas with the same vegetation type, but without such impacts for at least 10 years.

While forest areas normally suffer indirect and localized direct effects from management, grassland areas are directly impacted. Our findings have shown that species such as Monodelphis dimidiate (Wagner, 1847), Akodon sp. $2(2 \mathrm{n}=34)$ and Oxymycterus nasutus (Waterhouse, 1837), strictly associated with grasslands, are highly abundant in protected areas, but absent in impacted areas with the same kind of original vegetation. The lower spatial heterogeneity inside the impacted grasslands could be a reason for this absence.

Oligoryzomys nigripes was the most abundant species in this study, and the less demanding with regard to the degree of habitat conservation (Bonvicino et al. 2002). Nevertheless, only two individuals were found in grassland areas subject to frequent fire and livestock grazing. Even though we have not assessed the availability of shelter - which increases predation risk - or food in grasslands subject to frequent fire and grazing, these seem to be the main factors determining the absence of non-flying small mammal individuals in these impacted grassland habitats.

Some studies point out that fire incidents are followed by drastic declines in non-flying small mammal populations (FA \& SANChEZ-Cordero 1993). Recovery is relatively faster in sites where fire is frequent (Simons 1991, VieIra 1999), and where opportunist species are already present in the second month after disturbance (Соок JR 1959, Веск \& Vogl 1972, OJedA 1989, Fa \& Sanchez-Cordero 1993, Vieira \& Marinho-Filho 1998, Vieira 1999, Simon et al. 2002, Figueiredo \& Fernandez 2004). This pattern indicates that populations in sites regularly subjected to fire are better adapted to post-fire conditions. Although we have sampled grasslands with no fire incidents for up to 18 months, we have not found any non-flying small mammal species that are able to colonize or re-colonize areas subjected to frequent fires (every one or two years) and livestock grazing. This fact suggests that grazing is the most important factor here.

On the other hand, we have found one species, O. nigripes, to be more abundant in impacted forests, indicating its opportunistic character. This finding is consistent with the results of Dalmagro \& Vieira (2005), who showed that this rodent is associated with a low density of trees and limited canopy cover in the Araucaria forest. This pattern is attributed to forests with low recruitment of trees, which, in our case, would be an expected consequence of fire and livestock grazing and trampling on the impacted area.

Apparently, our findings differ from those of CARO (2001), carried out in a region dominated by dry deciduous forests in Tanzania. The author found richness and abundance of nonflying small mammals to be higher in areas affected by agriculture and cattle rearing than in a neighboring national park protected from anthropogenic impact. BILENCA et al. (2007) also had a high trapping success in a rural landscape, which they attributed to a greater availability of shelter (in cultivated fields), lower predation risk and lower competition with ungulates. In fact, these factors also seem to drive the dynamics of the species in non-flying small mammals, because in our study the greatest values of richness, abundance, diversity and biomass were found in protected areas. These protected areas presented greater cover and biomass in both tree and herb layers, a source of food and shelter from predators and harsh climatic conditions, only available in the absence of livestock.

Finally, the record of at least two new species (associated with grasslands) not yet described by science makes evident the urgent need for more studies in Araucaria forest ecotones. For instance, studies that correlate the assemblage of non-flying small mammals with microhabitat characteristics in grassland-Araucaria forest ecotones are very important. Moreover, the use and frequency of fire, and traditional livestock management practices, currently extensive and practiced with no restrictions to the use of forest patches, should be reviewed and minimized in order to ensure the preservation of the di- 
versity of non-flying mammals in grasslands-Araucaria forests ecotones. This study stresses the importance of conserving the forest-grassland mosaic of the south Brazilian highlands.

\section{ACKNOWLEDGEMENTS}

We thank the Pontifícia Universidade Católica do Rio Grande do Sul (PUCRS), specially Betina Blochtein and Ricardo Melo, and Mr. Escobar Marques, tenant of the Fazenda Três Estrelas, for the permission to carry out our field work in private properties. We also thank those who supported our field work, specially our colleague J. Cerveira. J. A de Oliveira (MNRJ), D. Jung and A. U. Christoff (ULBRA) confirmed species identifications and E. Giacomoni (UFRGS) provided assistance with the cytogenetic analyses used in the identification of some rodent species. We also thank IBAMA for issuing us a permit for capture and collection of animal specimens. G. S. Hofmann (UFRGS) and E. J. Weber (ULBRA) generated maps of the study area. J. M. de Oliveira (UFRGS) assisted in the quantitative analysis. A. Kindel, N. C. Cáceres, V. D. Pillar, C. R. Fonseca, H. Vasconcelos and one anonymous reviewer made comments and suggestions on the manuscript. The Conselho Nacional de Desenvolvimento Científico e Tecnológico (CNPq) granted a graduate scholarship to the first author during the study period and a research fellowship to S.M.H. (304036/2007-2).

\section{LITERATURE CITED}

Beск, A.M. \& R.J. Vogl. 1972. The effects of spring burning on rodent populations in a brush prairie savanna. Journal of Mammalogy 53 (2): 336-346.

Behling, H.; V.D. Pillar; L. Orlóci \& S.G. Bauermann. 2004. Late Quaternary Araucaria forest, grassland (Campos), fire and climate dynamics, studied by high-resolution pollen, charcoal and multivariate analysis of the Cambará do Sul core in southern Brazil. Palaeogeography, Palaeoclimatology, Palaeoecology 203 (3-4): 277-297.

Behling, H. \& V.D. Pillar. 2007. Late Quaternary vegetation, biodiversity and fire dynamics on the southern Brazilian highland and their implication for conservation and management of modern Araucaria forest and grassland ecosystems. Philosophical Transactions of the Royal Society B 362: 243-251.

Bilenca, D.N.; C.M. González-Fischer; P. Teta \& M. Zamero. 2007. Agricultural intensification and small mammal assemblages in agroecosystems of the Rolling Pampas, central Argentina. Agriculture, Ecosystems and Environment 121 (4): 371-375.

Bittencourt, E.B.; C.F. Vera y Conde; C.F.D. Rocha \& H.G. Bergallo. 1999. Activity patterns of small mammals in an Atlantic forest area of southeastern Brazil. Ciência e Cultura 51 (2): $126-132$.

Bonvicino, C.R.; S.M. Lindbergh \& L.S. Maroja. 2002. Small nonflying mammals from conserved and altered areas of Atlantic
Forest and Cerrado: comments on their potential use for monitoring environment. Brazilian Journal of Biology 62 (4B): 765-774.

BOWERS, M.A. 1988. Seed removal experiments on desert rodents: the microhabitat by moonlight effect. Journal of Mammalogy 69 (1): 201-204.

Brasil. 1969. Normais Climatológicas - São Paulo, Paraná, Santa Catarina e Rio Grande do Sul (1931-1960). Rio de Janeiro, Ministério da Agricultura, Escritório de Meteorologia, $74 \mathrm{p}$.

Brooks, T.M.; R.A. Mittermeier; C.G. Mittermeier; G.A.B. Fonseca; A.B. Rylands; W.R. Konstant; P. Flick; J. Pilgrim; S. Oldfield; G. Magin \& C. Hilton-Taylor. 2002. Habitat loss and extinction in the hotspots of biodiversity. Conservation Biology 16 (4): 909-923.

Brown, J.S.; B.P. Kotler; R.J. Smith \& W.O. Wirtz II. 1988. The effects of owl predation on the foraging behavior of heteromyid rodents. Oecologia 76 (3): 408-415.

Caro, T.M. 2001. Species richness and abundance of small mammals inside and outside an African national park. Biological Conservation 98 (3): 251-257.

Cochrane, M.A. \& M.D. Schulze. 1999. Fire as a recurrent event in tropical forests of the Eastern Amazon: effects on forest structure, biomass, and species composition. Biotropica 31 (1): 2-16.

Cochrane, M.A.; A. Alencar; M.D. Schulze; C.M. Souza; D.C. Nepstad; P. Lefebvre \& E.A. Davidson. 1999. Positive feedbacks in the fire dynamic of closed canopy tropical forests. Science 284 (5421): 1832-1835.

Cook JR, S.F. 1959. The effects of fire on a population of small rodents. Ecology 40 (1): 102-108.

Dalmagro, A.D. \& E.M. Vieira. 2005. Patterns of habitat utilization of small rodents in an area of Araucaria forest in Southern Brazil. Austral Ecology 30 (4): 353-362.

Duarte, L.S.; R.E. Machado; S.M. Hartz \& V.D. Pillar. 2006. What saplings can tell us about forest expansion over natural grasslands. Journal of Vegetation Science 17 (6): 799-808.

FA, J.E. \& V. SANCHEZ-Cordero. 1993. Small mammal responses to fire in a Mexican high-altitude grassland. Journal of Zoology (London) 230: 343-347.

Figueiredo, M.S.L. \& F.A.S. Fernandez. 2004. Contrasting effects of fire on populations of two small rodent species in fragments of Atlantic Forest in Brazil. Journal of Tropical Ecology 20 (2): 225-228.

Frank, D.A. \& R.D. Evans. 1997. Effects of native grazers on grassland $\mathrm{N}$ cycling in Yellowstone National Park. Ecology 78 (7): 2238-2248.

Frank, D.A. \& P.M. Groffman. 1998. Ungulate versus landscape control of soil $\mathrm{C}$ and $\mathrm{N}$ processes in grasslands of Yellowstone National Park. Ecology 79 (7): 2229-2241.

Kaufman, D.W. \& G.A. Kaufman. 1982. Effect of moonlight on activity and microhabitat use by Ord's kangaroo rat (Dipodomys ordii). Journal of Mammalogy 63 (2): 309-312. 
Köppen, W. 1948. Climatología: con un estudio de los climas de la tierra. Mexico, Fondo de Cultura Económica, 477p.

Manly, B.F.J. 1997. Randomization, Bootstrap and Monte Carlo Methods in Biology. London, Chapman and Hall, $2^{\text {nd }}$ ed., 399p.

Moreno, J.A. 1961. Clima do Rio Grande do Sul. Porto Alegre, Secretaria da Agricultura do Estado do Rio Grande do Sul, $42 \mathrm{p}$.

Moser, B.W. \& G.W. Witmer. 2000. The effects of elk and cattle foraging on the vegetation, birds, and small mammals of the Bridge Creek Wildlife Area, Oregon. International Biodeterioration and Biodegradation 45 (3-4): 151-157.

Myers, N.; R.A. Mittermeier; C.G. Mittermeier; G.A.B. Fonseca \& J. Kent. 2000. Biodiversity hotspots for conservation priorities. Nature 403 (6772): 853-858.

Nupp, T.E. \& R.K. SwiharT. 2000. Landscape-level correlates of small mammal assemblages in forest fragments of farmland. Journal of Mammalogy 81 (2): 512-526.

OJEDA, R.A. 1989. Small mammals responses to fire in the Monte Desert, Argentina. Journal of Mammalogy 70 (2): 416420.

Oliveira, J.M. \& V.D. Pillar. 2004. Vegetation dynamics on mosaics of Campos and Araucaria forest between 1974 and 1999 in Southern Brazil. Community Ecology 5 (2): 197202.

PILLAR, V.D. 2005. MULTIV versão 2.3.17: aplicativo para análise multivariada, testes de aleatorização e autoreamostragem. Porto Alegre, Departamento de Ecologia, Universidade Federal do Rio Grande do Sul (UFRGS).

Pillar, V.D. \& L. Orlóci. 1996. On randomization testing in vegetation science: multifactor comparisons of relevé groups. Journal of Vegetation Science 7 (4): 585-592.

Price, M.V. \& N.M. Waser. 1984. On the relative abundance of species: postfire changes in a coastal sage scrub rodent community. Ecology 65 (4): 1161-1169.
Price, M.V.; N.M. Waser \& T.A. Bass. 1984. Effects of moonlight on microhabitat use by desert rodents. Journal of Mammalogy 65 (2): 353-356.

Ribeiro, M.C.; J.P. Metzger; A.C. Martensen; F.J. Ponzoni \& M.M. Hirota. 2009. The Brazilian Atlantic Forest: How much is left, and how is the remaining forest distributed? Implications for conservation. Biological Conservation 142 (6): 1141-1153.

Simon, N.P.P.; C.B. Stratton; G.J. Forbes \& F.E. Schwab. 2002. Similarity of small mammal abundance in post-fire and clearcut forests. Forest Ecology and Management 165 (1): 163-172.

Simons, L.H. 1991. Rodent dynamics in relation to fire in the Sonoran desert. Journal of Mammalogy 72 (3): 518-524.

Teixeira, M.B. \& A.B. Coura Neto. 1986. Vegetação: As regiões fitoecológicas, sua natureza e seus recursos econômicos, p. 541-632. In: IBGE (Ed.). Folha SH.22 Porto Alegre e parte das Folhas SH.21 Uruguaiana e SI.22 Lagoa Mirim: geologia, geomorfologia, pedologia, vegetação, uso potencial da terra (Levantamento de Recursos Naturais, v. 33). Rio de Janeiro, Fundação Instituto Brasileiro de Geografia e Estatística, 796p.

Tilman, D. \& J.A. Downing. 1994. Biodiversity and stability in grasslands. Nature 367 (6461): 363-365.

Tilman, D.; D. Wedin \& J. Knops. 1996. Productivity and sustainability influenced by biodiversity in grassland ecosystems. Nature 379 (6567): 718-720.

VIEIRA, E.M. 1999. Small mammal communities and fire in the Brazilian Cerrado. Journal of Zoology (London) 249 (1): 75-81.

Vieira, E.M. \& J. Marinho-Filho. 1998. Pre and post fire habitat utilization by rodents of Cerrado from central Brazil. Biotropica 30 (3): 491-496.

ZAR, J.H. 1996. Bioestatistical analysis. Englewood Cliff (NJ), Prentice Hall, $3^{\text {rd }}$ ed., 662p.

Submitted: 03.IV.2009; Accepted: 27.VI.2010.

Editorial responsibility: Heraldo L. de Vasconcelos 